First Peoples Child \& Family Review

An Interdisciplinary Journal Honouring the Voices, Perspectives, and Knowledges of First Peoples through Research, Critical Analyses, Stories, Standpoints and Media Reviews

\title{
Stop the Hurting: Education and Health Care for All
}

\section{Beth Rhead}

Volume 9, numéro 2, 2014

Respect and Equity Through Reconciliation : special Edition by

Children and Youth

URI : https://id.erudit.org/iderudit/1077945ar

DOI : https://doi.org/10.7202/1077945ar

Aller au sommaire du numéro

Éditeur(s)

First Nations Child and Family Caring Society of Canada

ISSN

1708-489X (imprimé)

2293-6610 (numérique)

Découvrir la revue

Citer ce document

Rhead, B. (2014). Stop the Hurting: Education and Health Care for All. First Peoples Child \& Family Review, 9(2), 6-7. https://doi.org/10.7202/1077945ar d'utilisation que vous pouvez consulter en ligne. 


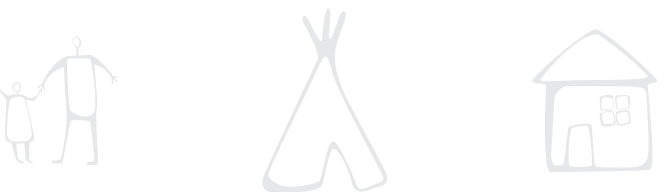

\section{Stop the Hurting: Education and Health Care for All}

\section{Beth Rhead}

Discrimination towards First Nations people has been going on for centuries. In the last fifty years or so, society has recognized many other injustices, such as discrimination based on the colour of one's skin or their gender, and has attempted to make changes in order to decrease discrimination. Why hasn't the same action been taken to stop the injustice facing Aboriginal children every day? Why can't our own government find a way to stop the hurting?

Our government, simply put, does not provide First Nations schools on reserves with enough funding to adequately support their students and help them realize their dreams. First Nations people also face underfunding in healthcare and social services, both of which are vital to one's well being. Why are such important services getting ignored? Why must the hurt to these children continue?

Education and healthcare for all is not a privilege, it is a right. Children on First Nations reserves are receiving these necessities but to a lesser degree than children such as I, off reserve. Shouldn't a country as wealthy as Canada be built on the notion of the highest level of care possible? The United Nations Convention on the Rights of the Child mandates that the highest level of services be provided, and does not make exceptions based on different levels of government footing your bill. Education and healthcare are free in this country, but they should also be equivalent, so providing some people with less money towards these services is not acceptable.

If we want a successful and productive nation we need to ensure the proper education of the youth, especially the fastest growing demographic of young people. In our economy, growth is important. To sustain growth, it will have to come from the service industry, people providing others with services not goods as we cannot keep on increasing our consumption of products. If our goal is to educate the population until Grade 12, who will be capable of performing these services? We want students to develop a love of learning so that they will be able to give back to society as an adult. But who would feel positive about school when they know that they are getting less? 
Most First Nations schools on reserve do not have the resources to provide their students with a class on their native language. First Nation languages all across this country are dying due to the lack of money to teach the young people. In some ways this is a twenty first century version of assimilation towards the First Nations people. Losing their language could also result in the loss of important stories for their culture and a loss of self-identity. If we want a diverse and open Canada for all people we need to support other cultures. Maybe a good place to start would be the culture that was here first. Most of the youth at my school plan to go on to college or university after graduating, to receive a higher education to hopefully lead to a better career. These opportunities should be within the reach of all Canadians far and wide. I have no idea of a career path yet for myself, but I have been given the opportunity to be able to choose my own way - an opportunity that all children deserve. No one should be dropping out of school because they feel it is inadequate. No one should have to learn with their coats and mitts still on in order to prevent frostbite. This is not equality and this is not justice. This is not how we should be educating our youth, who will become our future. 